\title{
Determining the perceptions of pre-service teachers on technology-based learning during the Covid-19 process: a latent class analysis approach
}

\author{
Bülent BAŞARAN ${ }^{1} \cdot$ Murat YALMAN $^{1}$
}

Received: 18 October 2021 / Accepted: 19 January 2022 / Published online: 10 February 2022

(C) The Author(s), under exclusive licence to Springer Science+Business Media, LLC, part of Springer Nature 2022

\begin{abstract}
In the study, latent class analysis (LCA) was used to determine the unobserved structures and the subpopulations of pre-service teachers' technology-based learning behaviours. According to LCA results, three latent classes were obtained. These classes are labelled as Class-1: "High-Level Technology Perception", Class-2: "Low-Level Technology Perception", Class-3: "Intermediate-Level Technology Perception". When Class-1(Reference Group) and Class-2 were compared, it was observed that the covariates of "gender" and "the Covid-19 pandemic affecting learning motivation" did not have a significant effect on Class-2. It has been determined that pre-service teachers who are older, studying in the 4th grade, using the Internet for more than $8 \mathrm{~h}$ a day, have advanced computer skills and have advanced technology-based learning experience are less likely to be in Class-2. In addition, in the study, while self-directed learning with technology was associated with preservice teachers' attitudes towards online teaching in the Covid-19 period and class membership, the fear of Covid-19 was not associated with latent class membership.
\end{abstract}

Keywords Latent class analysis · Covid-19 fear - Self-directed learning with technology $\cdot$ Online Education $\cdot$ Pre-service teachers

Bülent BAŞARAN

mumanenator@gmail.com; basaranb@gmail.com

1 Ziya Gökalp Education Faculty, Instructional Technologies, Dicle University, Diyarbakir, Turkey 


\section{Introduction}

With the digitalisation of today's investments, technology has gained a structure to serve all areas. The most important of these areas is education that contributes to human development. Although it has not been too long since the technology was used together with education, it can be said that they formed strong bonds between them (Yalman \& Tunga, 2014). This context has also led to the emergence of technologybased learning (TBL). TBL is a learning approach based on combining information and communication technologies such as visual media, digitised content, interactive video tools, graphics, or web-based interaction to fit students' learning style and enhance their abilities (Brumini et al.,2014). TBL, which is currently being used intensively in many levels of education, serves the same purpose even if it is discussed by researchers under different names such as distance learning, e-learning, blended learning, or computer-assisted education. The use of the Internet in many areas and the increase in the variety of devices we use (computers, tablets, mobile phones, etc.) have provided an easy adaptation of TBL to education. This situation has become even more critical, especially with the emergence of the Covid-19 pandemic, with education delivery through technology-based systems (Yalçınkaya, 2020). Students need a technological tool to at least follow their lessons has made the mobile phones they constantly use in their daily lives more functional. The primary purpose of TBL is to use technology as an educational tool in teaching (Yalman \& Başaran, 2018; Karadüz \& Baytak, 2010). In their study on teachers' technology integration, ChanLin, Horng, Chang, and Chu (2006) stated that teachers only use the technologies they use in the classroom to develop course materials and determine student success. It will make education more meaningful, especially for teachers and academics, to know for what purpose the equipment utilised for TBL is used. Kuo (2008), in his study investigating the perceptions of students towards internet-supported language education, stated that they should use other learning methods in this aspect, where the technological tools used in the classroom do not go beyond teaching the fundamental lessons. In this respect, different learning methods should be used. Ivers (2002) stated, in his study on teachers' use of technology in the classroom, that teachers who used technology as a tool in lessons didn't have enough self-confidence about technology. With the pandemic that emerged in this process, technology has become an indispensable part of education.

\subsection{Attitude towards TBL during the Covid-19 pandemic period}

During the Covid-19 pandemic, distance education has become mandatory in many national education and universities. In this process, the TBL method, which the students were not used to, causing them to be compared with traditional education. The students' success is possible with an in-depth examination of the methods used in TBL. Yağan (2021) investigated the attitudes towards distance education courses during the pandemic, with 272 students attending a university in central Anatolia. It has been determined that the students' attitudes in the research towards distance education are at a low level. He has also emphasised that students prefer face-to-face education (traditional) instead of such education methods. In addition, many studies 
evaluating the attitudes of university students towards distance education indicate that students' attitudes towards distance education are low, and they do not want to use this education method after the pandemic is over (Y1lmaz; 2020; Keskin \& Derya 2020; Kürtüncü \& Aylin 2020; Genç \& Gümrükçüoğlu, 2020; Kahraman 2020; Karatepe, Küçükgençay \& Peker 2020; Unger \& Meiran, 2020; Rizun \& Strzelecki 2020; Yalman, 2013). Studies show that students' attitudes towards distance education are at a low level during the Covid-19 pandemic period (Unger \& Meiran, 2020; Keskin \& Derya 2020; Kürtüncü \& Aylin 2020; Genç \& Gümrükçüoğlu 2020; Kahraman, 2020). The literature review shows that demographic characteristics such as gender, internet usage time, technology equipment used are not effective in the low attitudes of students towards distance education during the pandemic period (Al Salman, Alkathiri \& Khaled Bawaneh 2021; Y1lmaz 2020).

Furthermore, technical problems experienced in live lessons, internet connection problems, problems caused by sound and video, and the students' lack of motivation towards this system are shown as the reasons for the low attitudes of the students towards distance education (Keskin \& Derya, 2020; Kürtüncü \& Aylin, 2020; Genç \& Gümrükçüoğlu, 2020; Başaran et al., 2017). However, the increasing effects of the Covid-19 pandemic entail teaching with the distance education method instead of face-to-face education in the future. This process necessitates students to adopt distance education and increase their attitudes (Telli \& Altun, 2020).

\section{Fear of Covid-19 and its impact on education}

The education sector has also been adversely affected by the measures taken with the Covid-19 pandemic. In this period, partial or general curfews did not allow educational institutions to work. In this process, education has been done remotely and technology-based. Universities that made the necessary investments during the Covid-19 process and offered TBL as an alternative to their students experienced a comfortable transition period. Universities with insufficient information and infrastructure resources for TBL purchased commercial learning management systems and used them in their educational activities.

TBL model, students must have an internet connection and technological devices such as computers, tablets, or mobile phones to follow their lessons. In this period, when the pandemic manifested itself and death cases increased, students were asked to pursue their education processes with technology support. Covid-19 forces the person physically and psychologically (Ahorsu et al., 2020; Lin, 2020). In this emerging pandemic, it has been observed that the uncertainty of the mode of contagion and the fact that the treatment could not be determined increased the sense of uncertainty about the disease and deepened the level of anxiety (Doğan \& Düzel, 2020). Besides, it has also caused the adaptation problem of students to TBL, the fear of failing in the lessons, the fear of security, and the fear of losing (Alt \& Boniel-Nissim, 2018; Ellahi, 2017). Fear is often associated with anxiety (Van Bockstaele, Verschuere, Tibboel, Houwer, Crombez \& Koster, 2014). In addition, the proficiency of teachers who use TBL methods used to teach at universities and the lack of experience in live lessons have caused problems in learning (Chen \& Li, 2011; Li et al., 2018). Öz ceviz, 
Tektaş, Basmacı and Tektaş (2020) conducted a study on how the Covid-19 pandemic affects the anxiety levels of students attending different universities in Turkey. Their research determined that the stress levels of two-year school and institute students were higher than the other groups according to the school type variable. In their pilot study on university students in Bangladesh, Hossain, Ahmmed, Rahman, Sanam, Emran, and Mitra (2021) investigated whether the students' education processes were affected psychologically during the pandemic. They determined that more than $50 \%$ of the students had significant depressive and generalised anxiety disorders due to the Covid-19 pandemic. Although technology-supported classrooms are an alternative to traditional education, most students are not happy using the TBL method due to various psychological problems such as covid 19 anxiety (Hasan \& Bao, 2020).

\section{Self-directed learning with technology}

The increase in the use of technological tools in schools is directly proportional to the digital capacities of schools. An essential role in developing student attitudes towards information technologies falls on teachers (Teck \& Lai, 2011). Combining learning with technology and shaping it according to students' needs will accelerate learning and shorten it. In this respect, students will determine their own learning needs. Using information technologies in a self-directed learning model; will improve students' thinking skills, increase success, and increase the quality of education (Sánchez et al., 2011; Aypay, 2010; Hernandez Ramos, 2005; Lim \& Chai, 2004). The way students shape their learning needs is related to how they use information and communication tools in the self-directed learning process. Students who use self-directed learning with technology increase success and quality of education. The concept of TBL, which has increased its importance in the pandemic process, constitutes an essential step in determining the learning needs of the students. Technological tools are the most significant factor in pre-service teachers' participation in this process and choosing their own educational needs. The International Association for Technology in Education (ISTE) asks teachers to support students' information and communication technology literacy. This community expects students to acquire skills such as making good use of technology and encouraging the use of technology (International Society for Technology in Education, 2020). In this way, it will be easier for teachers to adapt to global education processes outside of today's education system. In this process, where education comes out of closed classrooms and is carried out with technology, it is needed to determine new educational goals by keeping the needs of students in the foreground. Of course, it is an expected and the desired destination in education for the student to centre the teacher as a guide. It is more and more important to teach and apply the technologies that students will use in basic learning activities in the future. Students' use of information and communication technologies in their lessons provides many advantages.

Thanks to self-directed learning with technology, students can make learning more permanent by using what they learned in traditional education more effectively. In addition, increasing the attitude towards learning provides many advantages such as active participation, educational planning according to the learning level and diver- 
sification of learning materials. (Çoklar, 2012; Luu \& Freeman, 2011; Chou, Hsiao, Shen \& Chen, 2010; Su, 2008). Self-directed learning with technology aims students to identify their own learning needs. In this method, students plan to improve themselves by reviewing their learning processes throughout their education (Williamson, 2007). In this context, since self-directed learning is related to technology integration, it can improve students' self-efficacy and knowledge.

\section{4 purpose of study and research questions}

This study aims to determine pre-service teachers' perceptions of TBL, which has become more critical with the Covid-19 pandemic. The relationship of TBL latent classes with "self-directed learning with technology", "attitudes of pre-service teachers towards online teaching during the Covid-19 period," and "fear of Covid-19" was examined. In addition, this study also focused on the effects of demographic (gender, age, classroom) characteristics, duration of internet use, computer usage skills, TBL experience and learning motivation variables of the Covid-19 pandemic on latent classes. In this context, answers to the following research questions (RQ) were sought. For this purpose, the following research questions are discussed:

- How many latent classes can be determined for TBL, and how many pre-service teachers per class?

- How do pre-service teachers' covariates such as gender, age, classroom differences, daily internet use, computer-TBL experiences, the effect of the Covid-19 pandemic on learning motivations differentiate class membership?

- To what extent are "self-directed learning with technology", "Students' Attitudes Towards Online Teaching in the period of Covid-19", and "fear of Covid-19" (distal outcomes) related to latent class membership? (Fig. 1)

Fig. 1 Latent class analysis model

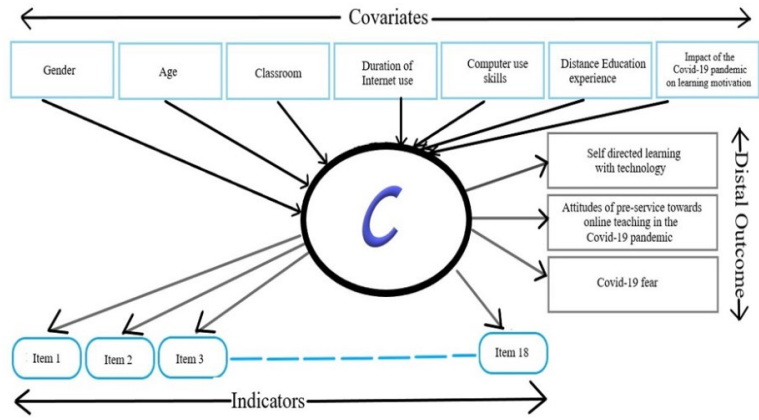




\section{Methods}

The person-centred LCA approach assumes the existence of unobserved latent variables that can be distinguished from each other, mutually exclusive and groups of individuals. Variable-centred analytical methods examine the relationships between variables under the assumption that the relationships between these variables in a population are homogeneous. In contrast, person-centred approaches examine the relationships between individuals under the belief that the relationships between these features are heterogeneous in a population (Masyn, 2013). While variable-centred methods such as regression modelling help identify relationships between independent and dependent variables and predict outcomes, person-centred approaches are helpful for enlightening groups of individuals to understand differences and similarities between individuals (Muthén \& Muthén, 2000).

The authors used LCA to identify unobserved (hidden) structures in the data. This method was preferred to investigate the subgroups of pre-service teachers' TBL behaviours. The LCA was used to statistically identify different subgroups or classes of individuals with similar response patterns to a set of questionnaire items. One

Table 1 Demographic information of pre-service teachers

\begin{tabular}{|c|c|c|}
\hline & $n(\%)$ & $M(\mathrm{SD})$ \\
\hline \multicolumn{3}{|c|}{ Demographic characteristics } \\
\hline \multicolumn{3}{|c|}{ Gender } \\
\hline Female & $268(67,3)$ & \multirow{8}{*}{$21,25(4,18)$} \\
\hline Male(Ref) & $130(32,7)$ & \\
\hline Age (range: $17-46$; medi & & \\
\hline \multicolumn{2}{|c|}{ Classroom } & \\
\hline 1st grade (Freshman) & $124(31,15)$ & \\
\hline 2nd grade (Sophomore) & $54(13,56)$ & \\
\hline 3rd grade (Junior) & $44(11,05)$ & \\
\hline 4th grade (Senior) & $79(19,84)$ & \\
\hline \multicolumn{3}{|l|}{ Daily Internet Usage Time } \\
\hline $0-2$ Hour & $84(21,1)$ & \\
\hline 3-4 Hour & $144(36,2)$ & \\
\hline 5-7 Hour & $123(30,9)$ & \\
\hline More than 8 hour & $47(11,8)$ & \\
\hline \multicolumn{3}{|l|}{ Computer use skills } \\
\hline Basic Level & $159(39,9)$ & \\
\hline Intermediate Level & $211(53)$ & \\
\hline Advance Level & $28(7)$ & \\
\hline \multicolumn{3}{|l|}{ TBL experience } \\
\hline Basic Level & $155(38,9)$ & \\
\hline Intermediate Level & $225(56,5)$ & \\
\hline Advance Level & $18(4,5)$ & \\
\hline \multicolumn{3}{|c|}{$\begin{array}{l}\text { The level of impact of the Covid-19 pandemic on learning } \\
\text { motivation }\end{array}$} \\
\hline Positive & $33(8,3)$ & \\
\hline Negative & $365(91,7)$ & \\
\hline
\end{tabular}


assumption of the LCA is that the class structure accounts for similar response patterns on the indicator variables in each class. Analyses have been made using the Mplus 8.1 program.

Eighteen variables were established to measure TBL behaviours (consisting of binary yes and no questions) in the study. Models from 1 to 7 have been created to determine the appropriate LCA modelling.

Table 2 Percentage distribution of the answers given by the pre-service teachers to the items

\begin{tabular}{|c|c|c|c|}
\hline & & $\begin{array}{l}\text { Yes } \\
(\%)\end{array}$ & $\begin{array}{l}\text { No } \\
(\%)\end{array}$ \\
\hline $\begin{array}{l}\text { Item } \\
1\end{array}$ & $\begin{array}{l}\text { I think TBL methods have achieved the desired } \\
\text { learning goals so far. }\end{array}$ & 11,8 & 88,2 \\
\hline $\begin{array}{l}\text { Item } \\
2\end{array}$ & $\begin{array}{l}\text { I think that TBL can replace traditional learning } \\
\text { methods }\end{array}$ & 17,8 & 82,2 \\
\hline $\begin{array}{l}\text { Item } \\
3\end{array}$ & $\begin{array}{l}\text { Watching TBL-supported lecture videos makes } \\
\text { me sleepy. }\end{array}$ & 59,5 & 40,5 \\
\hline $\begin{array}{l}\text { Item } \\
4\end{array}$ & $\begin{array}{l}\text { TBL makes it easier to communicate with my } \\
\text { teachers and classmates }\end{array}$ & 30,7 & 69,3 \\
\hline $\begin{array}{l}\text { Item } \\
5\end{array}$ & $\begin{array}{l}\text { Group discussions in lessons in TBL make me } \\
\text { think more about given assignments and topics }\end{array}$ & 45,2 & 54,8 \\
\hline $\begin{array}{l}\text { Item } \\
6\end{array}$ & Technology Web sites help to learn. & 78,9 & 21,1 \\
\hline $\begin{array}{l}\text { Item } \\
7\end{array}$ & Social media helps me learn my lessons & 42,2 & 57,8 \\
\hline $\begin{array}{l}\text { Item } \\
8\end{array}$ & $\begin{array}{l}\text { I want to communicate with my classmates and } \\
\text { teachers face-to-face because it is boring to } \\
\text { have virtual communication through technolog- } \\
\text { ical environments (groups such as WhatsApp } \\
\text { web). }\end{array}$ & 82,2 & 17,8 \\
\hline $\begin{array}{l}\text { Item } \\
9\end{array}$ & $\begin{array}{l}\text { Technology-Based lessons are more valuable } \\
\text { than traditional lessons. }\end{array}$ & 8,8 & 91,2 \\
\hline $\begin{array}{l}\text { Item } \\
10\end{array}$ & $\begin{array}{l}\text { It is better to combine technology and tra- } \\
\text { ditional learning in the educational process } \\
\text { (Blended Learning) }\end{array}$ & 77,4 & 22,6 \\
\hline $\begin{array}{l}\text { Item } \\
11\end{array}$ & $\begin{array}{l}\text { Technology-Based lessons need further im- } \\
\text { provement to support the learning process. }\end{array}$ & 94,5 & 5,5 \\
\hline $\begin{array}{l}\text { Item } \\
12\end{array}$ & $\begin{array}{l}\text { I believe that institutional (provided by univer- } \\
\text { sities) technical support is sufficient for me to } \\
\text { adopt TBL }\end{array}$ & 26,9 & 73,1 \\
\hline $\begin{array}{l}\text { Item } \\
13\end{array}$ & $\begin{array}{l}\text { I adapt well in the transition from traditional } \\
\text { learning to TBL }\end{array}$ & 24,1 & 78,9 \\
\hline $\begin{array}{l}\text { Item } \\
14\end{array}$ & $\begin{array}{l}\text { In TBL, lecturers can express the subjects } \\
\text { clearly in the lessons. }\end{array}$ & 70,1 & 29,9 \\
\hline $\begin{array}{l}\text { Item } \\
15\end{array}$ & $\begin{array}{l}\text { Instructors use existing technological tools } \\
\text { efficiently }\end{array}$ & 69,8 & 30,2 \\
\hline $\begin{array}{l}\text { Item } \\
16\end{array}$ & Instructors encourage us to use a TBL approach & 65,8 & 34,2 \\
\hline $\begin{array}{l}\text { Item } \\
17\end{array}$ & $\begin{array}{l}\text { Instructors communicate with us adequately } \\
\text { using technology or social media applications. }\end{array}$ & 61,8 & 38,2 \\
\hline $\begin{array}{l}\text { Item } \\
18\end{array}$ & $\begin{array}{l}\text { In general, instructors are active in helping us } \\
\text { during TBL }\end{array}$ & 80,4 & 19,6 \\
\hline
\end{tabular}




\section{Sample}

Our sample represents $20 \%$ of pre-service teachers studying at the education faculty. Since there was no missing data in the questionnaires used in the research, all of them were included in the analysis.

Research data were collected online in the 2019-2020 academic year from teacher candidates studying at the education faculty $(n=398)$ of a state university in the southeast of Turkey. Demographic variables related to students are given in Table 1.

\section{Indicator variables}

The researchers, considering the literature review, developed the study questions. Pre-service teachers' perceptions of TBL were measured with 18-item study questions. Each question is coded in "Yes" and "No" binary format. The percentage distributions of the responses given to the items are shown in Table 2.

\section{Covariates}

Covariates, which are predicted to affect pre-service teachers' perceptions of TBL, were included in the study to indicate whether each individual affected their class membership. These predictors are demographic (gender, age) characteristics, classroom, duration of internet use, computer use skills, TBL experience, and the impact of the Covid-19 pandemic on learning motivation. Age was taken as a continuous variable, while all other variables were categorical. These categorical variables are coded as dummy variables.

\section{Distal outcome}

\subsection{Self-directed learning with technology}

The Technology Self-Directed Learning Scale was developed by Tan, Chai, Lee, Teo, Chen, Koh, and Chen (2010). It was adapted into Turkish by Tercan, Horzum and Uysal (2014). While the internal consistency coefficient of the scale is calculated as 0.77 , it consists of 2 factors and six items as "Self-directed management" (2 Items) and "Purposeful Learning" (4 Items), and the items consist of a point Likert type between never (1), always (6). The highest 36 points and the lowest 6 points are taken from the scale. In our study, the internal consistency coefficient of the scale was calculated as 0.875 . 


\subsection{Attitudes of pre-service teachers towards online teaching in the Covid-19 period}

A 7-question survey measured pre-service teachers' attitudes towards online teaching during the Covid-19 period. The questions were scored between 1 and 5 (1- Strongly disagree...5-Strongly agree) using a 5-point Likert-type scaling. The survey consisted of the questions "I find it right to be given lessons with distance education system due to Covid-19 pandemic", "I prefer to be given lessons by distance education method after the danger of Covid-19 pandemic has passed", "After the danger of Covid-19 pandemic has passed, I would prefer the University to offer both formal and distance education applications to its students as an option", "I think Online education is a temporary solution during the Covid-19 pandemic", "I think that Online education is a mandatory solution for students to continue their learning process during the Covid-19 pandemic" and "I feel that the online education learning area given due to the Covid-19 pandemic has narrowed". In our study, the internal consistency coefficient of the survey was calculated as 0.702 .

\subsection{Covid-19 fear scale}

The Turkish adaptation, validity, and reliability of The Fear of COVID-19 Scale, developed by Ahorsu et al. (2020), was carried out by Satici, Gocet-Tekin, Deniz and Satici (2021). The applicable age scale is vast and can be used on university students and adults. All items of the scale consisting of 7 questions are scored positively. Using Likert-type scaling, the questions were scored between 1-5 (1- Strongly disagree...5-Strongly agree). There is no reverse-scored item on the scale. A score between 7 and 35 is taken from the scale. A high score indicates a 'high' level of fear of the COVID pandemic. In the scale's Turkish validity and reliability study, the Cronbach Alpha value was $(\alpha=0.82)$. In this study, the Cronbach Alpha value of the scale $(\alpha=0.903)$ has been found.

\section{Results}

In this section, the findings obtained from the research data are given based on the research questions. Akaike information criteria (AIC), Bayesian information criteria (BIC), and BIC adjusted for sample size (ABIC) were examined to find the best model. A model with lower AIC, BIC, and ABIC values is preferred. Two probabilistic indexes - Lo-Mendell-Rubin ratio test (LMRT) and bootstrap ratio test (BLRT) were used to compare the improvement in fit between a class $\mathrm{k}$ model and a class $\mathrm{k}-1$ model. Significant $\mathrm{p}$ values of LMRT and BLRT indicate that the k-class model is better than the $\mathrm{k}-1$-class model. Classification accuracy (i.e. entropy and class assignment probabilities) is also used to evaluate different models. Entropy and class assignment probabilities range from 0 to 1 , and a value close to 1 indicates good classification accuracy. Specifically, entropy above 0.80 and the assignment probability of each class above 0.80 indicate good classification quality. The reasonable sample size for each class should be over $5 \%$ of the total participants. 
According to the results, AIC and BIC values in the 3-class solution showed a sharp decrease compared to the 2-class solution cluster, but there was no marginal change in the BIC value in the 4-class cluster. While the non-significant LMRT of the 4-class solution $(p=0.119)$ shows that the 4-class solution is not better than the 3 -class solution, the significant LMRT of the 3-class solution $(p=0.000)$ has shown that the 3-class solution is better than the 2-class solution. The 3-class solution has a good classification accuracy (entropy $=0.868$ ), which is higher than the entropy value of the 2-class (entropy=0.788). However, model fit was examined using the elbow chart according to these indexes. Therefore, the 3-class solution was considered the best model according to multiple statistical criteria and theoretical interpretability. Item-response probabilities for three-class TBL are given in figure-2.

\subsection{Research question 1}

How many latent classes can pre-service teachers' perceptions of TBL be defined, and how many students are there per class?

\subsubsection{Class features:}

Class 1: high-level technology perception This class represents $12.06 \%(n=48)$ of the total sample. All of the pre-service teachers in this class said $100 \%$ yes to Item 13 (I adapt well in the transition from traditional learning to TBL), with the highest average. At the same time, we can be classified as the group with the highest motivation TBL.

Class 2: low-level perception of technology This class represents $33.16 \%(n=116)$ of the total sample. While $99.2 \%$ said no to Item 1 (I think TBL methods have achieved the desired learning goals so far.), which has the highest average of the pre-service teachers in this class, $0.8 \%$ said yes.

Class 3: intermediate level technology perception The largest class represents $54.77 \%$ of the total sample $(n=218)$. While the pre-service teachers in this class said $99.2 \%$ no to Item 9 (Technology-Based lessons are more valuable than traditional

Table 3 Comparison of LCA Model Fit Indices

\begin{tabular}{lllllll}
\hline Number of classes & AIC & BIC & ABIC & LMRT & BLRT & Entropy \\
\hline 1 & 7742.646 & 7814.402 & 7757.288 & - & - & - \\
2 & 7102.651 & 7250.150 & 7132.748 & 0.000 & 0.000 & 0.788 \\
3 & 6798.184 & 7021.426 & 6843.735 & 0.000 & 0.000 & 0.868 \\
4 & 6712.733 & 7011.717 & 6773.739 & 0.119 & 0.000 & 0.878 \\
5 & 6652.581 & 7027.307 & 6729.041 & 0.640 & 0.000 & 0.821 \\
6 & 6611.836 & 7062.306 & 6703.752 & 0.220 & 0.000 & 0.844 \\
7 & 6596.748 & 7122.959 & 6704.118 & 0.3525 & 0.000 & 0.855 \\
\hline
\end{tabular}




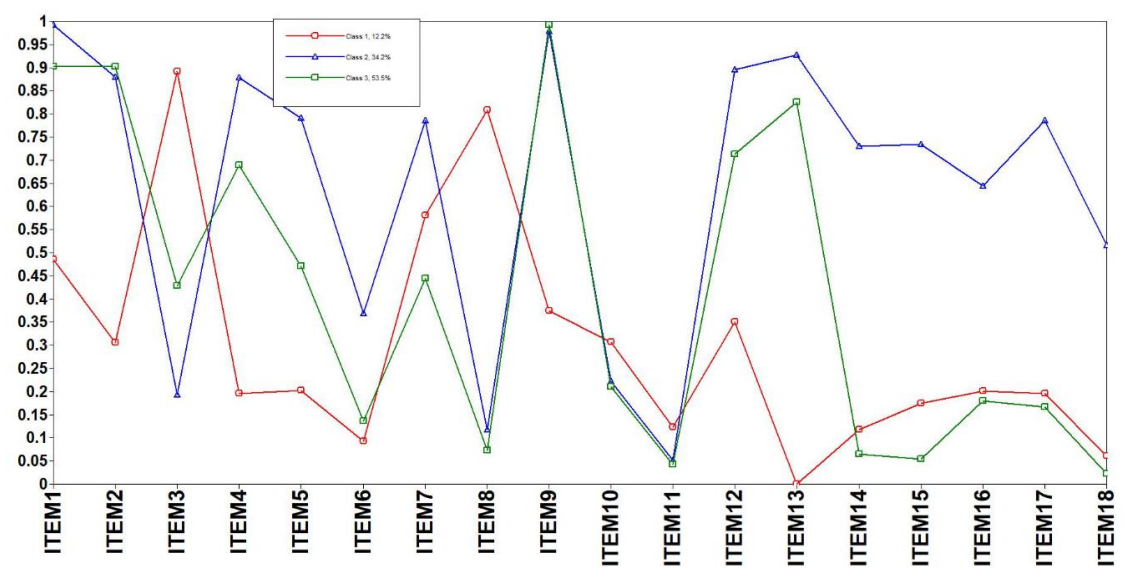

Fig. 2 3-class item response probabilities

lessons.) with the highest average, $0.8 \%$ of them said yes. It seems that pre-service teachers in this class are more committed to traditional methods.

\subsection{Research question 2}

Multinomial logistic regression analysis was performed to examine which covariates explained class membership for each of the identified latent classes. The R3Step technique (Asparouhov \& Muthén, 2014) was used in the analysis.

Table 4 shows the multinomial logistic regression findings that examine the demographic (gender, age) and educational experiences (Classroom, Daily Internet Use Time, computer use skills, TBL experience, impact of the Covid-19 Pandemic on learning motivation) associated with class membership. Class- 1 was used as the reference to explain the covariates. Covariates with a $p$-value of $\leq 0.05$ were considered significant. When Class-1 and Class-2 were compared, it was found that "gender" and "the impact of the Covid-19 pandemic on learning motivation" had no significant effect on covariates Class-2. Pre-service teachers who are older $(\mathrm{OR}=0.837), 4$ th grade $(\mathrm{OR}=0.241)$ and who use the internet more than $8 \mathrm{~h}$ a day $(\mathrm{OR}=0.240)$ are less likely to be in Class-2. Similarly, pre-service teachers with advanced computer skills $(\mathrm{OR}=0.813)$ and advanced TBL experience skills $(\mathrm{OR}=0.210)$ are less likely to be in Class-2. When Class-1 and Class-3 are compared, pre-service teachers who are older $(\mathrm{OR}=0.787)$, 3rd grade $(\mathrm{OR}=0.111), 4$ th grade $(\mathrm{OR}=0.163)$ and advanced computer skills $(\mathrm{OR}=0.140)$ is less likely to be in Class-3.

\subsection{Research question 3}

After the appropriate latent class model was determined, potential differences in distal outcomes between classes were examined using the BCH method (Bolck et al., 2004). This method uses posterior class membership probabilities, considers measurement 
Table 4 Demographic and educational experiences associated with latent class membership

\begin{tabular}{lll}
\hline Characteristic & Class-2: Low-Level & Class-3:Intermediate- \\
Demographics & Technology Perception & Level Technology \\
& OR $(95 \% \mathrm{CI})$ & Perception \\
& & OR $(95 \% \mathrm{CI})$ \\
\hline
\end{tabular}

\section{Gender}

Female (Ref)

Male $\quad 1.088[0.265-4.465] \quad 0.996[0.233-4.254]$

Age (range: $17-46 ; \quad \mathbf{0 . 8 3 7}[\mathbf{0 . 6 8 2}-\mathbf{1 . 0 2 7}] \quad \mathbf{0 . 7 8 7}[\mathbf{0 . 6 0 7 - 1 . 0 2 0}]$

median $=20$ )

Classroom

1st grade

(Freshman)

2nd grade

(Sophomore)

3rd grade (Junior)

1.931 [0.269-13.849] $\quad 0.708[0.090-5.544]$

$0.703[0.105-4.695] \quad \mathbf{0 . 1 1 1}[\mathbf{0 . 0 0 8}-\mathbf{1 . 5 1 8}]$

4th grade (Senior)

$0.241[0.021-2.832] \quad 0.163[0.019-1.425]$

Daily Internet

Usage Time

0-2 h (Ref)

$3-4 \mathrm{~h}$

$0.371[0.066-2.090] \quad 0.763[0.137-4.261]$

$5-7 \mathrm{~h}$

$0.415[0.067-2.576]$

$0.664[0.107-4.108]$

More than $8 \mathrm{~h}$

$\mathbf{0 . 2 4 0}[\mathbf{0 . 0 2 0}-\mathbf{2 . 8 1 8}] \quad 0.630[0.048-8.275]$

computer use skills

Basic Level (Ref)

Intermediate Level

Advance Level

0.690 [0.122-3.898] $\quad 0.669[0.119-3.764]$

$0.813[0.068-9.728] \quad 0.140[0.008-2.507]$

TBL experience

Basic Level (Ref)

Intermediate Level

Advance Level

0.207 [0.028-1.542] $0.544[0.068-4.360]$

$\mathbf{0 . 2 1 0}[\mathbf{0 . 0 2 6}-\mathbf{1 . 7 0 3}] \quad 0.269[0.024-3.054]$

The level of impact

of the Covid-19

pandemic on learning motivation

Positive (Ref)

Negative 64.128] 


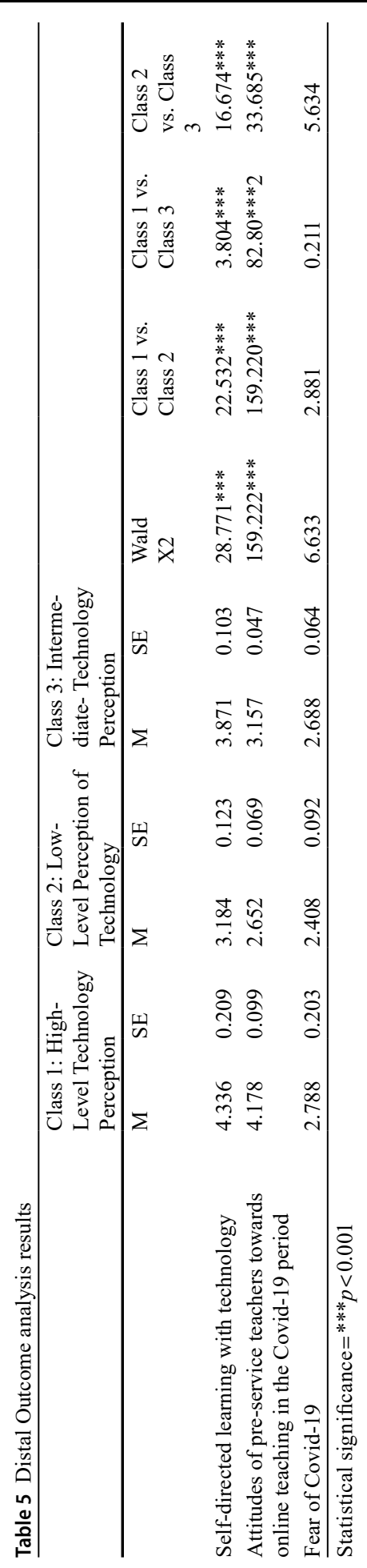


error without affecting the latent class structure, and avoids class shifts while estimating relationships between class membership and specified outcomes (Asparouhov \& Muthén, 2014). The BCH method uses Wald chi-square tests to compare results. The automated $\mathrm{BCH}$ method was used to investigate whether self-directed learning with technology, pre-service teachers' attitudes towards online teaching during the Covid-19 pandemic, and Covid-19 fear score mean create differences between latent classes (Table 5).

According to the results of the Wald chi-square analysis, self-directed learning with technology means scores showed significant differences between classes $(\chi$ $2=28.771, p<0.001$ ) (Table 3 ). The self-directed with technology score mean of preservice teachers was the highest in Class-1, while the mean score in Class-2 was the lowest. Likewise, pre-service teachers' attitudes towards online teaching in the Covid-19 period revealed significant differences between classes. $(\chi 2=159.222$, $p<0.001)$. It was observed that the pre-service teachers with the highest attitude mean were in Class-1, while the pre-service teachers with the lowest attitude mean were in Class-2. Wald chi-square analyses of pre-service teachers' mean fear of Covid-19 were insignificant in terms of mean between classes $(\chi 2=6.633, p>0.05)$. This result showed that the fear of Covid-19 has no relation with the classes created for students' technology perceptions.

\section{Discussion and conclusion}

The emergence of an unexpected pandemic has necessitated changes in normal daily activities and lifestyles, including teaching processes in educational institutions. In the current study, it was observed that $12.06 \%$ of the participants were delighted with their TBL experiences, $33.16 \%$ were dissatisfied, and $54.77 \%$ were moderately satisfied. This result shows that the majority of pre-service teachers have low TBL perceptions. A study has shown that online courses cause higher attrition for students than traditional learning (Terry, 2001). This can be attributed to the fact that the timing of online classes overlaps with personal and normal daily activities (Diaz, 2002).

Al-Taweel, Abdulkareem, Gul and Alshami (2021) investigated the satisfaction and attitudes of 830 dentistry students at Iraqi universities (Baghdad University, Sulaymaniyah University, and Dijlah University College) towards a tuberculosis course given online during the pandemic period. It was concluded that more than $50 \%$ of the students were not satisfied with TBL.

No significant difference was found between the classes based on gender in the study. Graham and Smith (2010) researched the differences in the African American population in terms of technology use and Internet activity. It was concluded that student characteristics (gender) affected technology use and adoption. Females typically reported higher computer self-efficacy, better user attitude, and lower computer anxiety than males. In a study made by Wu and Tsai (2006), it was determined that male students among undergraduate students had better Internet skills than female students. The effect of gender on technology perceptions is not conclusive. Still, most studies have shown that males have higher levels of computer and internet self-efficacy, more positive attitudes towards computers, and lower computer anxiety than 
females. Contrary to this result, some studies conclude that females' attitudes towards technology are higher than males. However, lately, it seems that gender differences in computer access and computer experience may have disappeared over time.

Another finding of the study is that the technology perceptions of the older preservice teachers are high. Looking at the studies conducted by Akkoyunlu and Orhan (2003), it is seen that younger people have more knowledge and skills in technology and have higher self-efficacy perceptions. Unlike these findings, Elkiran (2019) determined in his study that older students have higher technology self-efficacy perceptions. In addition, 4th grade students were less likely to be in class with a low perception of TBL. This result shows us that the 4th-grade students are more likely to be found in Class-1. In other words, it indicates that TBL perceptions are more favourable than their younger peers.

Lack of technical skills is one obstacle that negatively affects the TBL process (Khalil et al., 2018). In parallel with these results, TBL perceptions of 4th-grade students were more positive than 1 st-grade students. This is because 4 th-grade pre-service teachers are closer to the teaching profession than 1st-grade pre-service teachers, and they think more about using technology for educational purposes. Therefore, we believe that they develop their skills more because they use technology more in their lessons.

The pre-service teachers who have more than $8 \mathrm{~h}$ of internet connection frequency are less likely to be in class with a low perception of TBL. It can be said that the preservice teachers who have a high frequency of connecting to the Internet have high technology perceptions. Spending more hours online can give students more experience with the Internet, increasing their technology self-efficacy. It was determined that pre-service teachers with high computer skills have higher perceptions of technology. Pre-service teachers with little or no computer experience may fear the idea of using computers as part of their teaching practices. They may form strong negative attitudes towards using computers (Gonzalez, 2012).

One of the research findings is that pre-service teachers with high TBL experience are more likely to be found in Class-1. Studies have shown that teachers' proficiency in using computers is positively related to their perception of technology and intention to use it (Abbitt, 2011). Babić (2012) argues that the experience of using ICT equipment in the classroom helps teachers develop relevant skills and knowledge, which creates a positive attitude towards technology-rich learning environments. Holden and Rada (2011) state that the more experience a teacher has in using technology, the easier it will be to involve him in lessons. The expertise of technology-rich learning environments also reduces the anxiety levels associated with ICT. Previous widespread use of technology in the classroom can help teachers get used to technology, improving their attitudes towards using it in lessons (Kusano et al., 2013). Previous experience with computers has also been a positive factor contributing to teacher acceptance of various instructional technologies in the educational environment (Darby, 2011; Tweed, 2013). Eastin and LaRose (2000) also confirm the positive relationship between students' Internet self-efficacy and previous experiences with the Internet.

Another finding was that the impact of the Covid-19 pandemic on learning motivation did not have a significant effect on latent classes. In their study, Gonzalez, de 
la Rubia, Hincz, Lopez, Subirats, Fort, et al. (2020), Aguilera-Hermida (2020) stated that continuing their education online at home due to Covid-19 reduces their learning motivation. Learning at home can create a lack of motivation, for example, family obligations such as taking care of siblings or helping out at home; distractions like Netflix or online shopping; Factors such as the absence of a teacher or peer assistance and the lack of separation between home and school negatively affect students' motivation to learn.

\section{Discussion on distal outcome}

It was determined that while the mean score of Self-Directed Learning with Technology was the highest of the pre-service teachers in Class-1, the mean score of the pre-service teachers in Class- 2 was also the lowest. The rapid development of their technologies changes the way students choose their sources of information and increases learning opportunities in both formal and non-formal education (Fahnoe \& Mishra, 2013). The Covid-19 pandemic has made self-directed learning with technology more critical. This process has further increased the importance of studentcentred pedagogical approaches. Pre-service teachers in Class-1 can meet their own learning needs by taking the initiative without the support of others. In this way, they can choose learning objectives and materials suitably. As a result, pre-service teachers in Class-1 have more control in achieving their learning goals (Beach, 2017).

Pre-service teachers' attitude scores towards online teaching during the Covid-19 period revealed significant differences between latent classes. It was seen that the pre-service teachers with the highest mean score in online teaching attitude were Class-1, and the pre-service teachers with the lowest mean online teaching attitude scores were Class-2. During the Covid-19 pandemic process, the TBL perspectives of pre-service teachers have started to gain more importance. Various technological tools such as desktop computers, laptops, smartphones, smart devices, internet connections and platforms (software/mobile applications) are needed for online teaching. In this respect, the ability of pre-service teachers to achieve successful results in online education depends on their high TBL perceptions. It was observed that the positive perceptions of pre-service teachers towards TBL also positively affected their attitudes towards online teaching.

Pre-services teachers' fear of Covid-19 did not have a relationship with TBL latent classes. An essential extra feature that radically worsens the learning environment is that people develop high fear during the spread of Covid-19. However, as previous studies have highlighted, those negative emotions can hinder learning; the collective stress and anxiety from the pandemic can easily demotivate students and prevent them from learning (Pekrun et al., 2017). Such changes can be associated with various mental health problems and negatively affect university students' quality of life and academic performance. According to this finding, the fear of Covid-19 has not caused a change in the perceptions of pre-service teachers about TBL.

Conflict of interest None. 


\section{References}

Abbitt, J. T. (2011). Hizmet öncesi öğretmen eğitiminde teknolojik pedagojik alan bilgisinin ölçülmesi: Mevcut yöntem ve araçların gözden geçirilmesi. Eğitimde Teknoloji Araştırmaları Dergisi, 43(4), 281-300. https://doi.org/10.1080/15391523.2011.10782573

Aguilera-Hermida, A. P. (2020). College students' use and acceptance of emergency online learning due to COVID-19. International Journal of Educational Research Open, 1, 100011. https://doi. org/10.1016/j.ijedro.2020.100011

Ahorsu, D. K., Lin, C. Y., Imani, V., Saffari, M., Griffiths, M. D., \& Pakpour, A. H. (2020). The fear of COVID-19 scale: development and initial validation. International journal of mental health and addiction, 1-9. https://doi.org/10.1007/s11469-020-00270-8

Akkoyunlu, B., \& Orhan, F. (2003). Bilgisayar ve ögretim teknolojileri egitimi (BÖTE) bölümü ögrencilerinin bilgisayar kullanma öz yeterlik inanci ile demografik özellikleri arasindaki iliski. TOJET: The Turkish Online Journal of Educational Technology, 2(3)

Al Salman, S., Alkathiri, M., \& Khaled Bawaneh, A. (2021). School off, learning on the identification of preference and challenges among school students towards distance learning during COVID19 outbreak. International Journal of Lifelong Education, 40(1), 53-71. https://doi.org/10.1080/0260 1370.2021.1874554

Al-Taweel, F. B., Abdulkareem, A. A., Gul, S. S., \& Alshami, M. L. (2021). Evaluation of technologybased learning by dental students during the pandemic outbreak of coronavirus disease 2019. European Journal of Dental Education, 25(1), 183-190. https://doi.org/10.1111/eje.12589

Alt, D., \& Boniel-Nissim, M. (2018). There are links between adolescents' deep and surface learning approaches, problematic Internet use, and fear of missing out (FOMO). Internet interventions, 13, 30-39. https://doi.org/10.1016/j.invent.2018.05.002

Asparouhov, T., \& Muthén, B. (2014). Mplus Web Notes: No. 15, Version 8, August 5, 2014. Auxiliary variables in mixture modelling: 3-Step approach using Mplus

Aypay, A. (2010). Information and communication technology (ICT) usage and achievement of Turkish students in PISA 2006. Turkish Online Journal of Educational Technology-TOJET, 9(2), 116-124

Babić, S. (2012). Factors that influence academic teacher's acceptance of e-learning technology in blended learning environment. E-learning-organizational infrastructure and tools for specific areas, 3-18

Başaran, B., Yalman, M., \& Erkan, S. (2017). Evaluation of Students' Attitudes towards e-Exams and Use of Technology in Theology Distance Undergraduate Education Programs. Hitit Üniversitesi Ilahiyat Fakültesi Dergisi, 16(31), 277-299

Beach, P. (2017). Self-directed online learning: A theoretical model for understanding elementary teachers' online learning experiences. Teaching and Teacher Education, 61, 60-72. https://doi.org/10.1016/j. tate.2016.10.007

Bolck, A., Croon, M., \& Hagenaars, J. (2004). Estimating latent structure models with categorical variables: One-step versus three-step estimators. Political Analysis, 12(1), 3-27

Brumini, G., Špalj, S., Mavrinac, M., Biočina-Lukenda, D., Strujić, M., \& Brumini, M. (2014). Attitudes towards e-learning amongst dental students at the universities in C roatia. European Journal of Dental Education, 18(1), 15-23

ChanLin, L. J., Hong, J. C., Horng, J. S., Chang, S. H., \& Chu, H. C. (2006). Factors influencing technology integration in teaching: A Taiwanese perspective. Innovations in Education and Teaching International, 43(1), 57-68

Chen, E., \& Li, Z. (2011, July). On the application of multimedia technology in foreign language teaching and learning in China's colleges: Challenges, problems and implications. In 2011 International Conference on Multimedia Technology (pp. 595-597). IEEE

Chou, C. M., Hsiao, H. C., Shen, C. H., \& Chen, S. C. (2010). Analysis of Factors in Technological and Vocational School Teachers' Perceived Organizational Innovative Climate and Continuous Use of E-Teaching: Using Computer Self-Efficacy as an Intervening Variable. Turkish Online Journal of Educational Technology-TOJET, 9(4), 35-48

Çoklar, M. (2012). Genel ögretmen yeterlikleri içerisinde bilgi ve iletişim teknolojileri: Afyonkarahisar ili örneği (Master's thesis, Necmettin Erbakan Üniversitesi)

Darby, V. M. (2011). Öğretmenlerin öğretim uygulamalarını güçlendirmek için ilköğretim sınıflarında teknoloji aşılama algıları (Yayımlanmamış doktora tezi). Nova Güneydoğu Üniversitesi, Ft. Lauderdale 
Doğan, M. M., \& Düzel, B. (2020). Covid-19 özelinde korku-kaygı düzeyleri. Electronic Turkish Studies, $15(4)$

Diaz, D. P. (2002). Online drop rate revisited. Extending the Pedagogy of Threaded-Topic Discussions, 2002(1)

Eastin, M. S., \& LaRose, R. (2000). Internet self-efficacy and the psychology of the digital divide. Journal of computer-mediated communication, 6(1), JCMC611

Elkiran, Y. M. (2019). Türkçe öğretmeni adaylarının teknoloji entegrasyonu yeterlikleri ile öğretmenlik özyeterlikleri arasındaki ilişki

Ellahi, A. (2017, December). Fear of using technology: Investigating impact of using social networking sites in business education. In 2017 IEEE 15th student Conference on research and development (SCOReD) (pp. 234-237). IEEE. https://doi.org/10.1109/SCORED.2017.8305387

Fahnoe, C., \& Mishra, P. (2013, March). Do 21st century learning environments support self-directed learning? Middle school students' response to an intentionally designed learning environment. In Society for information technology \& teacher education international conference (pp. 3131-3139). Association for the Advancement of Computing in Education (AACE)

Genç, M. F., \& Gümrükçüoğlu, S. (2020). Koronavirüs (Covid-19) Sürecinde İlâhiyat Fakültesi Öğrencilerinin Uzaktan Eğitime Bakışları. Electronic Turkish Studies, 15(4)

Gonzalez, T., de la Rubia, M., Hincz, K., Lopez, M. C., Subirats, L., Fort, S., et al. (2020). Influence of COVID-19 confinement in students' performance in higher education. https://doi.org/10.35542/osf. io/9zuac

Gonzalez, Y. (2012). An analysis of teachers' concerns toward the implementation of instructional technology in the curriculum (Unpublished doctoral dissertation). Nova Southeastern University, Ft. Lauderdale

Graham, R., \& Smith, D. T. (2010). Dividing lines: An empirical examination of technology use and Internet activity among African-Americans. Information, Communication \& Society, 13(6), 892-908. https://doi.org/10.1080/13691180903514344

Hasan, N., \& Bao, Y. (2020). Impact of “e-Learning crack-up” perception on psychological distress among college students during COVID-19 pandemic: A mediating role of "fear of academic year loss". Children and Youth Services Review, 118, 105355. https://doi.org/10.1016/j.childyouth.2020.105355

Hernández-Ramos, P. (2005). If not here, where? Understanding teachers' use of technology in Silicon Valley schools. Journal of Research on Technology in education, 38(1), 39-64

Holden, H., \& Rada, R. (2011). Understanding the influence of perceived usability and technology selfefficacy on teachers' technology acceptance. Journal of Research on Technology in Education, 43(4), 343-367

Hossain, M. J., Ahmmed, F., Rahman, S. A., Sanam, S., Emran, T. B., \& Mitra, S. (2021). Impact of online education on fear of academic delay and psychological distress among university students following one year of COVID-19 outbreak in Bangladesh. Heliyon, 7(6), e07388. https://doi.org/10.1016/j. heliyon.2021.e07388

Ivers, K. S. (2002). Changing Teachers' Perceptions and Use of Technology in the Classroom

International Society for Technology in Education (2020). https://www.iste.org/ [Access Date:4/2021]

Kahraman, M. E. (2020). COVID-19 salgınının uygulamalı derslere etkisi ve bu derslerin uzaktan eğitimle yürütülmesi: Temel tasarım dersi örneği. Medeniyet Sanat Dergisi, 6(1), 44-56. https://doi. org/10.46641/medeniyetsanat.741737

Karadüz, A., \& Baytak, A. (2010). Teknoloji Destekli Öğretimin Türkçe Eğitimi Bölümü Öğrencileri Tarafından Nasıl Algılandığının İncelenmesi. Sakarya Üniversitesi Eğitim Fakültesi Dergisi, 20, 7-29

Karatepe, F., Küçükgençay, N., \& Peker, B. (2020). Öğretmen adayları senkron uzaktan eğitime nasıl bakıyor? Bir anket çalışması. Journal of social and humanities sciences research, 7(53), 1262-1274. https://doi.org/10.26450/jshsr. 1868

Keskin, M., \& Derya, Ö. Z. E. R. (2020). COVID-19 sürecinde öğrencilerin web tabanlı uzaktan eğitime yönelik geri bildirimlerinin değerlendirilmesi. İzmir Katip Çelebi Üniversitesi Sağllk Bilimleri Fakültesi Dergisi, 5(2), 59-67. Retrieved from https://dergipark.org.tr/en/pub/ikcusbfd/ issue $/ 55773 / 754174$

Khalil, M. K., Abdel Meguid, E. M., \& Elkhider, I. A. (2018). Teaching of anatomical sciences: A blended learning approach. Clinical Anatomy, 31(3), 323-329. https://doi.org/10.1002/ca.23052

Kusano, K., Frederiksen, S., Jones, L., Kobayashi, M., Mukoyama, Y., Yamagishi, T., et al. (2013). The effects of ICT environment on teachers' attitudes and technology integration in Japan and the U.S. Journal of Information Technology Education, 12, 30-43 
Kuo, M. M. (2008). Learner to Teacher: EFL Student Teachers' Perceptions on Internet-Assisted Language Learning and Teaching. Online Submission

Kürtüncü, M., \& Aylin, K. U. R. T. (2020). COVID-19 pandemisi döneminde hemşirelik öğrencilerinin uzaktan eğitim konusunda yaşadiklari sorunlar. Avrasya Sosyal ve Ekonomi Araştırmaları Dergisi, 7(5), 66-77. Retrieved from https://dergipark.org.tr/en/pub/asead/issue/54658/725503

Li, L., Chen, Y., Li, Z., Li, D., Li, F., \& Huang, H. (2018, August). Online virtual Experiment teaching platform for Database technology and application. In 2018 13th International Conference on Computer Science \& Education (ICCSE) (pp. 1-5). IEEE. https://doi.org/10.1109/ICCSE.2018.8468849

Lim, C. P., \& Chai, C. S. (2004). An activity-theoretical approach to research of ICT integration in Singapore schools: Orienting activities and learner autonomy. Computers \& Education, 43(3), 215-236

Lin, C. Y. (2020). Social reaction toward the 2019 novel coronavirus (COVID-19). Social Health and Behavior, 3(1), 1. https://doi.org/10.4103/SHB.SHB1120

Luu, K., \& Freeman, J. G. (2011). An analysis of the relationship between information and communication technology (ICT) and scientific literacy in Canada and Australia. Computers \& Education, 56(4), 1072-1082

Masyn, K. E. (2013). 25 latent class analysis and finite mixture modeling. The Oxford handbook of quantitative methods, 2, 551

Muthén, B., \& Muthén, L. K. (2000). Integrating person-centered and variable-centered analyses: Growth mixture modeling with latent trajectory classes. Alcoholism: Clinical and experimental research, 24(6), 882-891

Öz Ceviz, N., Tektaş, N., Basmacı, G., \& Tektaş, M. (2020). Covid-19 pandemi sürecinde üniversite öğrencilerinin uzaktan eğitime bakışı: Türkiye örneği. Ulakbilge, 52, 1322-1335. https://doi. org/10.7816/ulakbilge-08-54-06

Pekrun, R., Lichtenfeld, S., Marsh, H. W., Murayama, K., \& Goetz, T. (2017). Achievement emotions and academic performance: Longitudinal models of reciprocal effects. Child development, 88(5), 1653-1670. https://doi.org/10.1111/cdev.12704

Rizun, M., \& Strzelecki, A. (2020). Students' acceptance of the Covid-19 impact on shifting higher education to distance learning in Poland. International Journal of Environmental Research and Public Health, 17(18), 6468. https://doi.org/10.3390/ijerph17186468

Sánchez, J., Salinas, Á., \& Harris, J. (2011). Education with Ict in South Korea and chile. International Journal of Educational Development, 31(2), 126-148

Satici, B., Gocet-Tekin, E., Deniz, M., \& Satici, S. A. (2021). Adaptation of the Fear of COVID-19 Scale: Its association with psychological distress and life satisfaction in Turkey. International journal of mental health and addiction, 19(6), 1980-1988. https://doi.org/10.1007/s11469-020-00294-0

$\mathrm{Su}, \mathrm{K}$. D. (2008). An integrated science course designed with information communication technologies to enhance university students' learning performance. Computers \& Education, 51(3), 1365-1374

Teck, S. H., \& Lai, Y. L. (2011). An empirical analysis of Malaysian pre-university students' ICT competency gender differences. International Journal of Network and Mobile Technologies, 2(1)

Tan, S. C., Chai, C. S., Lee, C. B., Teo, K. G. T., Chen, W., Koh, J. ... Cheah, H. M. (2010). Evaluation of implementation of the IT Masterplan 3 and its impact on Singapore schools.Instrumentation and baseline study. Research Brief, (11-001)

Telli, S. G., \& Altun, D. (2020). Coronavirüs ve Çevrimiçi (Online) Eğitimin Önlenemeyen Yükselişi. Üniversite Araştırmaları Dergisi, 3(1), 25-34. https://doi.org/10.32329/uad.711110

Tercan, S. S., Horzum, M. B., \& Uysal, M. (2014).TEKNOLOJI İLE ÖZ-YÖNELİMLİ ÖĞRENME ÖLÇEĞİNIN TÜRKÇE'YE UYARLANMASI

Terry, N. (2001). Assessing enrollment and attrition rates for the online MBA. The Journal, 28(7), 64-68

Tweed, S. (2013). Technology implementation: Teacher age, experience, self-efficacy, and professional development as related to classroom technology integration (Doctoral dissertation, East Tennessee State University)

Unger, S., \& Meiran, W. R. (2020). Student Attitudes towards Online Education during the COVID-19 Viral Outbreak of 2020: Distance Learning in a Time of Social Distance. International Journal of Technology in Education and Science, 4(4), 256-266. https://files.eric.ed.gov/fulltext/EJ1271377.pdf

Van Bockstaele, B., Verschuere, B., Tibboel, H., De Houwer, J., Crombez, G., \& Koster, E. H. W. (2014). A review of current evidence for the causal impact of attentional bias on fear and anxiety. Psychological Bulletin, 140(3), 682-724. https://doi.org/10.1037/a0034834

Williamson, S. N. (2007). Development of a self-rating scale of self-directed learning. Nurse researcher, $14(2)$ 
Wu, Y. T., \& Tsai, C. C. (2006). University Students' Internet Attitudes and Internet Self-Efficacy: AStudy at Three Universities in Taiwan. Cyberpsychology \& behavior, 9(4), 441-450

Yalçınkaya, O. D., \& Perspectives on Challenges of Teaching Foreign Language Online Across The World. (2020). Academic Studies in Educational Sciences-II, 113

Yalman, M., \& Başaran, B. (2018). Web 2.0 Araçlarıyla Geliștirilen Uzaktan Eğitim Materyallerine Yönelik Eğitim Fakültesi Öğrencilerinin Görüşleri. AJIT-e: Bilişim Teknolojileri Online Dergisi, 9(34), 81-95. https://doi.org/10.5824/1309-1581.2018.4.006.x

Yalman, M., \& Tunga, M. A. (2014). Examining the attitudes of students from state and foundation universities in Turkey towards the computer and www (world wide web). Egitim ve Bilim, 39(173)

Yalman, M. (2013). Eğitim fakültesi öğrencilerinin bilgisayar destekli uzaktan eğitim sistemi (moodle) memnuniyet düzeyleri. Electronic Turkish Studies, 8(8)

Yağan, S. A. (2021). Üniversite Öğrencilerinin COVID-19 Salgını Sürecinde Yürütülen Uzaktan Eğitime Yönelik Tutum ve Görüşleri. Akademik Platform Eğitim ve Değişim Dergisi, 4(1), 147-174. Retrieved from https://dergipark.org.tr/en/pub/apjec/issue/62988/942141

Yılmaz, N. A., \& YÜKSEKÖĞRETIM KURUMLARINDA COVID-19 PANDEMİİ SÜRECINDE UYGULANAN UZAKTAN EĞİTIM DURUMU HAKKINDA ÖĞRENCİLERİN TUTUMLARININ ARAŞTIRILMASI: FIZYOTERAPİ ve REHABİLITASYON BÖLÜMÜ ÖRNEĞİ. (2020). Necmettin Erbakan Üniversitesi Sağlık Bilimleri Fakültesi Dergisi, 3 (1), 15-20. Retrieved from https://dergipark.org.tr/en/pub/neufhsj/issue/55814/751395

Publisher's note Springer Nature remains neutral with regard to jurisdictional claims in published maps and institutional affiliations. 